\title{
FAKTOR-FAKTOR YANG MEMPENGARUHI PENYEMBUHAN LUKA GANGRENE PADA PENDERITA DIABETES MELLITUS DI RUANG RAWAT INAP RSUD DR. PIRNGADI MEDAN
}

\author{
Soep $^{1}$, Cecep Triwibowo ${ }^{1}$ \\ ${ }^{1}$ Jurusan Keperawatan Poltekkes Kemenkes RI Medan
}

\begin{abstract}
Gangrenous wound healing is a state of gangrenous wounds experienced by patients with diabetes mellitus who said recovered and not recovered already passed the stage of the physiological process of wound healing gangrenous. Wound healing is a condition of the wound which has undergone phase of the physiological process of wound healing to say cured or not cured. Gangrenous wound healing is influenced by age, nutrition, wound care. The general objective of this study to determine the factors that affect wound healing in diabetes mellitus gangrene in inpatient hospital DR.Pirngadi Medan in 2015. This research uses descriptive method with cross sectional study design. With accidential sampling techniques, sample size studied 20 respondents. Data collected by using observation sheets and questionnaires. The data obtained were analyzed manually through editing, coding, and tabulating presented in frequency distribution. Conclusion: gangrenous wound healing respondents said recovered as many as 17 people (85\%), based on age ie 40-50 years as many as 10 people (50\%) based nutrients are met as many as 14 people (70\%), based on those wounds care done correctly by $20(100 \%)$.
\end{abstract}

Keywords: Factors, Gangrenous Wound Healing, DM

\section{A. Latar Belakang}

Diabetes melitus (DM) atau kencing manis merupakan penyakit menahun yang ditandai dengan meningkatnya kadar glukosa darah dan gangguan metabolisme karbohidrat, lemak, dan protein yang disebabkan oleh kekurangan hormon insulin. Menurut Smeltzer (2002), diabetes melitus merupakan sekelompok kelainan heterogen yang ditandai oleh kenaikan kadar glukosa darah atau hiperglikemia. Prevalensi penderita diabetes pada tahun 1985 sebesar 30 juta orang, meningkat menjadi 135 juta orang pada tahun 1995 dan 217 juta orang pada tahun 2005 (Smyth \& Heron, 2006). Lima negara dengan jumlah penderita diabetes terbesar pada tahun 2000 adalah India dengan 31,7 juta, Cina orang 20,8 juta, Amerika 17,7 juta orang, Indonesia 8,4 juta orang, dan Jepang 6,8 juta orang (Wild, Roglic, Green, Sicree, \& King, 2004). Berdasarkan data yang diperoleh dari data Survailans Terpadu Penyakit (STP) tahun 2008 terlihat jumlah kasus yang paling banyak adalah penyakit Diabetes Melitus dengan jumlah kasus DM mencapai 918 pasien yang ada di 123 rumah sakit 28 kabupaten/kota seluruh propinsi Sumatera Utara, data Riskesdas (2007) prevalensi Diabetes Melitus yang didiagnosa oleh Nakes (tenaga kesehatan) disertai dengan gejala diperoleh data untuk kabupaten Samosir $0.3 \%$, Dairi $1 \%$, Serdang bedagai $0.6 \%$, Tapanuli Utara $0.3 \%$, prevalensi DM untuk kota Medan 2.7\% dan prevalensi DM untuk propinsi Sumatera Utara
$1.98 \%$, sementara data terakhir yang dikeluarkan Depkes RI menyatakan prevalensi DM secara nasional adalah 5.7\% (Depkes, 2009).

DM adalah salah satu penyakit kronis yang memerlukan penatalaksanaan jangka panjang. Kondisi - kondisi pada penyakit kronis menuntut klien untuk beradaptasi terhadap perubahan - perubahan tersebut agar tidak terjadi komplikasi (Qurratuaeni, 2009). DM adalah sekelompok penyakit metabolik yang dikarakteristikan dengan kondisi hiperglikemia yang diakibatkan oleh gangguan dalam sekresi insulin, aksi insulin, ataupun keduanya. Komplikasi akut yang mengancam nyawa pada Diabetes adalah hiperglikemia berat dengan ketoasidosis atau nonketotik hiperosmolar syndrome. Komplikasi jangka panjang dari DM adalah retinopati, gagal ginjal kronis, neuropati perifer yang menyebabkan ulkus kaki dan amputasi, charcot joint, neuropati otonom yang menyebabkan gejala gastrointestinal, genitourinari, kardiovaskuler, dan disfungsi seksual. Pasien dengan diabetes berisiko tinggi untuk mengalami aterosklerosis, penyakit jantung koroner, dan stroke. Selain itu hipertensi dan profil lipoprotein yang abnormal sering ditemui pada penderita DM (BIMIKI, 2014).

Menurut kriteria diagnostik Perkumpulan Endokrinologi Indonesia (PERKENI) tahun 2006, seseorang didiagnosa menderita Diabetes Mellitus jika mempunyai kadar glukosa darah sewaktu $>200 \mathrm{mg} / \mathrm{dl}$ dan kadar glukosa darah puasa $>126 \mathrm{mg} / \mathrm{dl}$. Manifestasi 
klinis Diabetes Mellitus yang sangat khas adalah meningkatnya frekuensi berkemih (poliuria), rasa haus berlebihan (polidipsia), rasa lapar yang semakin besar (polifagia), keluhan lelah dan mengantuk, serta penurunan berat badan (Price, 2005).

Komplikasi lain dari DM adalah kerentanan terhadap infeksi, tuberculosis paru, dan infeksi pada kaki, yang kemudian dapat berkembang menjadi gangren. Gangren adalah proses atau keadaan yang ditandai dengan adanya jaringan mati atau nekrosis (Waspadji, 2006). Gangren kaki diabetik luka pada kaki yang merah kehitam-hitaman dan berbau busuk akibat sumbatan yang etrjadi di pembuluh darah sedang atau besar di tungkai. Luka gangren merupakan salah satu komplikasi kronik DM yang paling ditakuti oleh setiap penderita DM (Tjokroprawiro, 2007).

Pada penderita DM dengan luka gangren perbaikan perfusi mutlak diperlukan karena hal tersebut akan sangat membantu dalam pengangkutan oksigen dan darah ke jaringan yang rusak. Peran perawat disini adalah melakukan perawatan luka dengan baik serta selalu melakukan pengkajian dan penilaian terhadap perfusi jaringan yang luka, penilaian granulasi jaringan serta menilai proses penyembuhan luka ganggren tersebut (Gitarja,2008)

Prevalensi luka ganggren di Indonesia sekitar $15 \%$ dari prevalensi pasien diabetes melitus, angka amputasi 30\%, angka mortalitas $32 \%$ dan luka diabetik merupakan penyebab perawatan rumah sakit yang terbanyak sebesar 80\% untuk DM (Hastuti,2008). Luka ganggren merupakan keadaan yang di awali dari adanya hipoksia jaringan dimana oksigen dalam jaringan berkurang, hal tersebut akan mempengaruhi aktivitas vaskuler dan seluler jaringan sehingga akan berakibat terjadinya kerusakan jaringan (Guyton, 2006).

Kerusakan pada jaringan menyebabkan kerusakan pada pembuluh darah. Sel, platelet dan kolagen tercampur dan mengadakan interaksi. Lekosit melekat pada sel endotel pembuluh darah mikro setempat, pembuluh darah yang rusak akan tersumbat tetapi pembuluh darah yang ada didekatnya, terutama venula dengan cepat akan mengadakan dilatasi. Lekosit bermigrasi diantara sel-sel endotel ke tempat yang rusak dan dalam beberapa jam tepi daerah jaringan yang rusak sudah diinfiltrasi oleh granulosit dan makrofag. Lekosit yang rusak segera digantikan oleh fibroblas yang juga sedang bermetabolisme dengan cepat, sehingga dibutuhkan kemampuan sirkulasi yang besar, tetapi keadaan tersebut tidak didukung oleh sirkulasi yang baik sehingga hal itu dapat menyebabkan hipoksia jaringan (Subekti, 2006).

Berdasarkan survey pendahuluan yang dilakukan di RSUD dr.Pirngadi Medan pada tanggal 21 februari 2015 diperoleh jumlah data dan penderita penyakit diabetes melitus yang menjalani pengobatan pada tahun 2014 sebanyak 310 penderita dan 62 Berdasarkan latar belakang diatas maka perlu dilakukan penelitian tentang "Penyembuhan Luka gangren Pada Penderita Diabetes Melitus Di Ruang Dahlia I RSUD dr.Pirngadi Medan tahun 2015".

\section{B. Metodologi Penelitian}

Penelitian ini dilakukan dengan menggunakan metode penelitian Deskriptif yang menggambarkan keadaan sebenarnya (Notoadmodjo, 2010). Dan dengan menggunakan desain penelitian Cross Sectional yaitu suatu metode yang merupakan rancangan penelitian dengan melakukan pengukuran dan pengamatan pada saat bersamaan (Sesekali sewaktu). Dan penelitian ini dilakukan pengambilan sampel sampel yaitu dengan menggunakan teknik accidental sampling yaitu mengambil responden yang klebetulan ada atau tersedia ditempat sesuai konteks penelitian dengan batas 20 orang.

\section{Hasil Penelitian}

Dari lembar observasi yang telah dilaksanakan dan lembar kuesioner yang telah disebarkan kepada 20 responden di ruang Dahlia I, Dahlia II, Mawar I, Mawar ii, RSUD DR. Pirngadi Medan tahun 2015,maka diperoleh,kemudian diolah dan dianalisa serta disajikan dalam bentuk tabel distribusi frekuensi seperti dibawah ini:

Tabel 1. Distribusi Frekuensi Berdasarkan Usia Responden di RSUD DR.Pirngadi Medan Tahun 2015

\begin{tabular}{ccc}
\hline Usia & Frekuensi & Presentase $(\%)$ \\
\hline $40-50$ & 12 & 60 \\
$50-60$ & 5 & 25 \\
$60-70$ & 3 & 15 \\
\hline Total & 20 & 100 \\
\hline
\end{tabular}

Berdasarkan tabel diatas menunjukkan bahwa mayoritas responden berusia 40-50 tahun sebanyak 12 orang $(60 \%)$, Minoritas sebanyak 5 orang $(25 \%)$ berusia 51-60 tahun dan 3 orang (15\%) berusia 61-70 tahun (15\%).

Tabel 2. Distribusi Frekuensi Berdasarkan Nutrisi Responden Luka Gangren di RSUD DR.Pirngadi Medan Tahun 2015.

\begin{tabular}{ccc}
\hline Nurisi & Frekuensi & Presentase $(\%)$ \\
\hline Terpenuhi & 16 & 80 \\
Tidak Terpenuhi & 4 & 20 \\
\hline Total & 20 & 100
\end{tabular}

Berdasarkan tabel diatas menunjukkan bahwa mayoritas responden mempunyai nutrisi yang terpenuhi selama proses penyembuhan luka ganggren yaitu sebanyak 16 orang $(80 \%)$ dan minoritas tidak terpenuhi sebanyak 4 orang $(20 \%)$.

Tabel 3. Distribusi Frekuensi Berdasarkan Perawatan Luka Pasien Luka Gangren di RSUD DR.Pirngadi Medan Tahun 2015

\begin{tabular}{ccc}
\hline Perawatan Luka & Frekuensi & Presentase $(\%)$ \\
\hline Benar & 20 & 100 \\
Tidak Benar & 0 & 0 \\
\hline Total & 20 & 100
\end{tabular}

Berdasarkan tabel diatas menunjukkan bahwa mayoritas perawatan luka dikakukan dengan benar terhadap responden sebanyak 20 orang (100\%), dan tidak ada yang tidak benar. 
Tabel 4. Distribusi Frekuensi Berdasarkan Penyembuhan Luka Gangren di RSUD DR.Pirngadi Medan Tahun 2015

\begin{tabular}{ccc}
\hline Penyembuhan Luka & Frekuensi & Presentase (\%) \\
\hline Sembuh & 17 & 85 \\
Tidak Sembuh & 3 & 15 \\
\hline Total & 20 & 100 \\
\hline
\end{tabular}

Berdasarkan tabel diatas menunjukkan bahwa mayoritas penyembuhan luka responden yaitu sembuh sebanyak 17 orang $(85 \%)$ dan Minoritas Tidak sembuh sebanyak 3 orang $(15 \%)$.

Tabel 5. Distribusi Frekuensi Berdasarkan Penyembuhan Luka Responden Berdasarkan Usia di RSUD DR.Pirngadi Medan Tahun 2015.

\begin{tabular}{lllllllll}
\hline $\begin{array}{l}\text { Penyembu } \\
\text { han }\end{array}$ & \multicolumn{9}{c}{ Usia } & & & To & $\%$ \\
\cline { 2 - 7 } & $40-50$ & $\%$ & $51-60$ & $\%$ & $61-70$ & $\%$ & tal & \\
\hline Sembuh & 10 & 50 & 4 & 20 & 3 & 15 & 17 & 85 \\
$\begin{array}{l}\text { Tidak } \\
\text { Sembuh }\end{array}$ & 2 & 10 & 1 & 5 & 0 & 0 & 3 & 15 \\
\hline Total & 12 & 60 & 5 & 25 & 3 & 15 & 20 & 100 \\
\hline
\end{tabular}

Berdasarkan tabel diatas menunjukkan bahwa mayoritas penyembuhan luka ganggren responden yang dikatakan sembuh berdasarkan usia adalah responden pada saat berusia $40-50$ tahun sebanyak 10 orang $(50 \%)$ dan minoritas saat berusia 51-60 tahun yaitu sebanyak 4 orang (20\%) dan saat berusia 60-71 yaitu sebanyak 3 orang $(15 \%)$.

Tabel 6. Distribusi Frekuensi Berdasarkan Penyembuhan Luka Responden Berdasarkan Nutrisi di RSUD DR.Pirngadi Medan Tahun2015

\begin{tabular}{|c|c|c|c|c|c|c|}
\hline \multirow{2}{*}{$\begin{array}{c}\text { Penyembuhan } \\
\text { Luka }\end{array}$} & \multicolumn{4}{|c|}{ Nutrisi } & \multirow{2}{*}{\multicolumn{2}{|c|}{ Total $\%$}} \\
\hline & Terpenuhi & $\%$ & $\begin{array}{l}\text { Tidak } \\
\text { Terpenuhi }\end{array}$ & $\%$ & & \\
\hline Sembuh & 14 & 70 & 2 & 10 & 16 & 80 \\
\hline Tidak Sembuh & 3 & 15 & 1 & 5 & 4 & 20 \\
\hline Total & 17 & 75 & 3 & 15 & 20 & 100 \\
\hline
\end{tabular}

Berdasarkan tabel diatas menunjukkan bahwa mayoritas penyembuhan luka ganggren responden yang dikatakan sembuh berdasarkan nutrisi yaitu responden dengan nutrisi yang terpenuhi sebanyak 14 orang (70\%) dan minoritas dengan nutrisi tidak terpenuhi sebanyak 2 orang (10\%). Maka dengan total penyembuhan luka responden yang dapat sembuh baik dengan nutrisi terpenuhi atau tidak terpenuhi sebanyak 16 orang (80\%). Sedangka minoritas penyembuhan luka responden yang dikatakan tidak sembuh, sedangkan minoritas penyembuhan luka luka gangren responden dikatakan tidak sembuh sebanyak 3 orang (15\%) dengan nutrisi terpenuhi dan 1 orang $(5 \%)$ dengan nutrisi tidak terpenuhi dengan total penyembuhan luka gangren yang tidak sembuh sebanyak 4 orang (20\%).
Tabel 7. Distribusi Frekuensi Berdasarkan Penyembuhan Luka Responden Berdasarkan Perawatan Luka di RSUD DR.Pirngadi Medan Tahun 2015

\begin{tabular}{|c|c|c|c|c|c|c|}
\hline \multirow{2}{*}{$\begin{array}{c}\text { Penyembuhan } \\
\text { Luka }\end{array}$} & \multicolumn{4}{|c|}{ Perawatan Luka } & \multirow[t]{2}{*}{ Total } & \multirow[t]{2}{*}{$\%$} \\
\hline & Benat & $\%$ & $\begin{array}{l}\text { Tidak } \\
\text { Benar }\end{array}$ & $\%$ & & \\
\hline Sembuh & 17 & 85 & 3 & 15 & 20 & 100 \\
\hline Tidak Sembuh & 0 & 0 & 0 & 0 & 0 & 0 \\
\hline Total & 17 & 85 & 3 & 15 & 20 & 100 \\
\hline
\end{tabular}

Berdasarkan tabel diatas menunjukkan penyembuhan luka ganggren dengan harapan sembuh sebanyak 20 orang (100\%) baik itu dengan perawatan luka yang benar maupun perawatn luka yang tidak benar.

\section{Pembahasan}

Peneliti membahas faktor-faktor yang mempengaruhi penyembuhan luka ganggren pada penderita diabetes mellitus di Ruang rawat inap RSUD Dr. Pirngadi Medan Tahun 2015. Adapun yang dibahas adalah:

1. Usia

Banyak faktor yang mempengaruhi penyembuhan luka, salah satunya yaitu usia. Dari hasil tabel 4.5 menunjukkan bahwa dari 20 responden paling banyak yang berusia 40-50 tahun mengalami penyembuhan luka dengan kriteria sembuh sebanyak 10 orang $(50 \%)$, pada usia 51-60 sebanyak . Hasil penelitian ini sesuai dengan pendapat atau teori (Harman, 2007) yang mengatakan bahwa usia anak sampai dewasa memiliki penyembuhan luka yang lebih cepat daripada orang tua. Hal ini dikarenakan orang tua mengalami penurunan fungsi multi organ, sehingga bila dipertanyakan kenapa tidak pada usia yang semakin tua penyembuhan luka bisa dapat sembuh? maka jawabannya karena hal itulah yang dapat menyebabkan proses penyembuhan luka menjadi lebih panjang atau tertunda sehingga lama penyembuhan luka tersebut. Dan kenapa paling banyak pada usia 40-50 tahun terkena diabetes melitus?. Hal itu dikarenakan manusia mengalami penurunan fisiologis setelah umur 40 tahun. Diabetes melitus sering muncul setelah memasuki umur rawan tersebut. Semakin bertambahnya umur, maka resiko menderita diabetes mellitus akan meningkat terutama umur 45 tahun dengan disebut kelompok resiko tinggi (Harman, 2007).

\section{Nutrisi}

Penyembuhan luka membutuhkan nutrisi yang tinggi. Pasien memerlukan diet tinggi protein, vitamin a, c, b12, zat besi, dan kalsium (Harman, 2007), dan hal ini sesuai dengan hasil peneliti dari tabel 2 menunjukkan bahwa dari 20 responden paling banyak 14 orang (70\%) nutrisi yang terpenuhi yaitu dengan mengkonsumsi diet tinggi protein, vitamin A, C, B12, zat besi, dan kalsium dapat mengalami penyembuhan luka dengan kriteria sembuh. Jadi, dari hasil tersebut dapat disimpulkan bahwa pasien dengan nutrisi terpenuhi akan lebih cepat mengalami kesembuhan lukanya. 


\section{Perawatan Luka}

Selain usia dan nutrisi, perawatan luka juga termasuk faktor-faktor yang mempengaruhi penyembuhan luka pada pasien diabetes melitus (Harman, 2007). Dari hasil tabel 4.7 menunjukkan bahwa dari 20 responden yang melakukan perawatan luka dengan benar ada 17 orang (85\%) mengalami penyembuhan luka dengan kriteria sembuh, dan tidak ada responden yang tidak mengalami penyembuhan luka dengan kriteria tidak sembuh, dan ada responden perawatan lukanya yang tidak benar (tidak melakukan perawatan luka sesuai langkah-langkah perawatan luka tang telah ditentukan) masih bisa mengalami penyembuhan luka dengan kriteria sembuh sebanyak 3 orang (15\%). Dikatan dengan kriteria sembuh yaitu bila luas luka berkurang, jumlah exudate/nanah berkurang, jaringan luka tersebut semakin baik, ada pertumbuhan jaringan granulasi atau jaringan baru, dan luka tersebut mengalami warna kemerahan. Hal ini dapat disimpulkan bahwa perawatan luka baik ituh dilakukan dengan benar dan tidak benar tetap saja akan mengalami penyembuhan luka dengan kriteria sembuh, akan tetapi bila perawatan luka dilakukan dengan benar maka penyembuhan luka dengan kriteria sembuh dapat dialami dengan cepat, sedangkan perawatan dengan tidak benar dilakukan maka dibutuhkan waktu yang lama untuk dapat mengalami penyembuhan luka dengan kriteria sembuh.

\section{Penyembuhan Luka}

Setelah didapatkan hasil dari penelitian ini, maka faktor-faktor yang mempengaruhi penyembuhan luka dapat terjadi dengan cepat atau tidak disebabkan oleh usia, nutrisi yang dikomsumsi dengan diet tinggi, dan cara perawatan luka yang yang benar. Dari hasil penelitian bahwa besar penyembuhan luka difaktori oleh perawatan luka sebanyak $85 \%$, nutrisi $70 \%$, dan usia 50\%. Hal ini menunjukkan bahwa bila cara perawatan luka yang dilakukan dengan benar ditambah dengan nutrisi yang dikomsumsi pasien diabetes melitus dengan diet tinggi (protein, vitamin a, c, b12, zat besi, dan kalsium) yang disebut dengan nutrisi terpenuhi, dan tanpa melihat faktor dari usia golongan tua dan muda responden tetap dapat mengalami penyembuhan luka dengan kriteria sembuh.

\section{E. Kesimpulan}

1. Penyembuhan luka gangren lebih cepat pada usia $40-50$ tahun yaitu sebanyak 12 orang $(60 \%)$ yang mengalami proses penyembuhan dari 20 orang.

2. Penyembuhan luka gangren lebih cepat jika nutrisinya terpenuhi yaitu sebanyak 14 (70\%) yang mengalamiproses penyembuhan dari 20 orang.

3. Penyembuhan Luka gangren lebih cepat jika perawatan luka dilakukan dengan benar yaitu sebanyak $17(85 \%)$ orang yang mengalami proses penyembuhan dari 20 orang.

\section{F. Saran}

1. Untuk responden yang usianya semakin tinggi supaya lebih memperhatikan gaya hidup karena semakin tinggi usia seseorang akan mengalami penurun fungsi multi organ yang menyebabkan lamanya penyembuhan luka

2. Untuk responden, lebih memperhatikan nutrisi dengan mengkonsumsi diet tinggi vitamin A, C, B12, Zat Besi, Protein, dan Kalsium, agar dapat mengalami penyembuhan luka yang cepat sembuh.

3. Untuk tim kesehatan diharapkan supaya melakukan perawatan luka sesuai SOP untuk memperoleh hasil atau penyembuhan luka yang cepat.

\section{Daftar Pustaka}

Anonim. (2015). WhatIs Diabetes. Http:www.Medicinenet.com/diabetes_melitus/ articlehtm\#.Diakses bulan februari 2015

Asih, Okti Rahayu. (2010). Hubungan Komponen Persepsi terhadap Penyakit dengan Tindakan Pengendalian Kadar Gula Darah pada Penderita DM Tipe 2 di Poliklinik Khusus Penyakit Dalam RSUP Dr. M. Djamil Padang Tahun 2010.Skripsi. Padang : Universitas Andalas

Belchetz, Paul et al. (2003). Mosby's color atlas and text of Diabetes and Endocrinology. London : Elsevier Science Limited Bilous.R.W.(2002).

Seri Kesehatan:Bimbingan Dokter Pada Diabetes.Jakarta P.Dian Rakyat.

Foster.DW(1998).Diabetes Melitus;Textbook of Endocrinology. USA.WB. Saunders Co. Fryberg.R.G.et al.(2000)Diabetik Foot Disorder;a Clinical Practice GuidlineUSA.Data Trace Publishing.

Greenspan.FS.\&Baxter.JD.(2000).Endokrinlogi Basic dan Klinik edisi 4.Alih Bahasa Wijaya.c.et al.Jakarta .EGC.

Johnson.m.(1998).Diabetes;Terapi dan Pencegahannya .Bandung.Indonesia Publishing House.

Olina, Zilfa. (2008). Hubungan Pengetahuan dan SIkap Klien Diabates Mellitus (DM) Tentang Pencegahan Ulkus Diabetikum Dengan Kejadian Ulkus DIabetikum di IRNA C Penyakit Dalam RSUP. Dr. M. Djamil Padang Tahun 2008. KTI. Padang: Politeknik Kesehatan Padang Departemen Kesehatan Padang

PERKENI. (2006). Konsensus Pengelolaan dan Pencegahan Diabetes mellitus Tipe 2 di Indonesia. Jakarta : PB. PERKENI

Price, S. A. (2005). Patofisiologi : Konsep Klinis ProsesProses Penyakit (Edisi 6.Vol 2). Jakarta : EGC

Rana Kusuma(1982),Diabetes Melitus,UI Press,Jakarta.

Rochsismandoko, Endang. (2003). Faktor-Faktor yang Mempengaruhi Penderita DM Tipe 2 Rawat Jalan di RS Persahabatan Jakarta. Dalam Jurnal Persahabatan. Vol 3 No 1

Sabri,L.\&Hastono,SP.(2008).Statistik Kesehatan. Edisi 3, Jakarta.Rajawali Press.

Smeltzer, S.Bare,B. (2002). Buku Ajar Keperawatan Medikal Bedah

Brunner \& Suddarth. Ed.8. Vol 2. Jakarta: EGC. 
Soewondo,P(2002).Pemantauan Pengendalian Diabetes Melitus:Dalam Penata Laksanaan Diabetes Melitus Terpadu .Jakarta;FKUI.

Subekti.(2006).Neuropati Diabetik.Ilmu Penyakit Dalam .Jakarta.Balai Penerbit FKUI

Syono,dkk.(2001).,Buku Ajar Ilmu Penyakit Dalam,Jakarta :Balai Penerbit FKUI.

Tjokroprawiro,A.(2007).Buku Ajar Ilmu penyakit Dalam, Surabaya.Airlangga Uneversity Press.

Waspadji,S.(2006).Komplikasi Kronik Diabetes.Buku Ajar Ilmu Penyakit Dalam edisi 3 Jakarta.Balai Penerbit Fakultas Kedokteran Universitas Indonesia.
Wikipedia.(2015).Diabetes Melitus,Http;//www.clinical diabaetes mellitus./article. htm\#.diakses Februari 2015

WHO,2008.The World Health Organization Quality Of Life (WHOQoL) Switzerland,Diakses Bulan Januari 2015

Zuraidah.2015. Panduan Penyusunan Karya Tulis Ilmiah .Medan; Politeknik Kesehatan Kemenkes Medan 